\title{
IMPLEMENTASI PENDEKATAN KONSTRUKTIVISME TIPE SNOWBALL THROWING DALAM PEMBELAJARAN MENULIS PUISI DI KELAS VII MTS HIDAYATUL ISLAMIYAH BUMIREJO
}

\author{
Bisarul Ihsan \\ Universitas Islam Darul 'Ulum Lamongan \\ bisarul@unisda.ac.id
}

\begin{abstract}
Abstact : This study aims to (1) describe the results of learning to write poetry using the Snowball Throwing type constructivism approach, (2) describe student activities, (3) describe students' responses to the learning process using the Snowball Throwing type constructivism approach. The results of this study are (1) the acquisition of students' cognitive abilities in understanding learning about poetry with the results of an average value of 90.2. (2) Student activities during the learning process are quite active, with the percentage of active students equaling 91.3 (21 students), and inactive students 8.7 (2 students). (3) Results of student responses with the percentage of students who responded to the Yes category by $66.92 \%$, Less categories by $32.98 \%$, and No categories by $0 \%$.
\end{abstract}

Keywords: constructivism approach, Snowball Throwing model, writing poetry

\begin{abstract}
Abstrak: Penelitian ini bertujuan untuk (1) mendeskripsikan hasil pembelajaran menulis puisi dengan menggunakan pendekatan konstruktivisme tipe Snowball Throwing, (2) mendiskripsikan aktifitas siswa, (3) mendiskripsikan respon siswa terhadap proses pembelajaran dengan menggunakan pendekatan konstruktivisme tipe Snowball Throwing. Hasil penelitian ini ialah (1) pemerolehan kemampuan kognitif siswa dalam memahami pembelajaran tentang puisi dengan hasil nilai rata-rata 90,2. (2) Aktivitas siswa selama proses pembelajaran cukup aktif, dengan persentase siswa aktif sebesar 91,3 (21 siswa), dan siswa yang tidak aktif 8,7 (2 siswa). (3) Hasil respon siswa dengan persentase siswa yang merespon kategori Ya sebesar 66,92\%, kategori Kurang sebesar 32,98\%, dan kategori Tidak sebesar 0\%.
\end{abstract}

Kata kunci: pendekatan konstruktivisme, model Snowball Throwing, menulis puisi

\section{PENDAHULUAN}

Pendidikan merupakan salah satu yang menjadi tumpuan harapan untuk meningkatkan kualitas sumber daya manusia (SDM) bangsa Indonesia. Selain itu pendidikan juga menjadi sarana bagi pembentukan intelektualitas, bakat, budi pekerti atau akhlak, serta kecakapan peserta didik (Zubaedi, 2005:v). Maka jelas sudah begitu pentingnya pendidikan di suatu negara karena salah satu faktor yang dapat menjadikan negara tersebut maju ialah dilihat dari kualitas SDM yang dimiliki oleh negara tersebut.

Sedangkan yang menjadi salah satu masalah yang dihadapi dunia pendidikan Indonesia ialah lemahnya proses pembelajaran. Dalam proses pembelajaran, anak kurang didorong untuk mengembangkan kemampuan berpikir. Proses pembelajaran di dalam kelas diarahkan kepada kemampuan anak untuk menghafal informasi, otak anak dipaksa untuk mengingat dan menimbun 
berbagai informasi tanpa dituntut untuk memahami informasi yang diingatnya untuk menghubungkannya dengan kehidupan sehari-sehari. Seharusnya pembelajaran ialah usaha guru untuk membentuk perilaku siswa sesuai dengan tujuan yang diinginkan (Sularmi, 2018). Hal ini mengakibatkan ketika seorang peserta didik sudah lulus, mereka pandai secara teoritis, namun mereka kurang mumpuni dalam hal mengaplikasikan di kehidup sehari-hari. Maka dibutuhkan pendidikan karakter untuk meningkatkan kemampuan pribadi seorang peserta didik.

Seiring dengan pengembangan filsafat konstruktivisme dalam pendidikan selama dekade ini, muncul pemikiran kritis merenovasi pembelajaran bagi anak bangsa negeri ini menuju pembelajaran yang lebih berkualitas, humanis, organis, dinamis, dan konstruktif. Salah satu pemikiran kritis itu adalah pembelajaran aktif, inovatif, kreatif, efektif, dan menyenangkan. (Yusnimarniarti, 2016) menjelaskan Pembelajaran konstruktivisme merupakan cara untuk memcahkan suatu masalah. Hal inilah yang seharusnya dibutuhkan oleh peserta didik sehingga bisa diimplementasikann dalam kehidupan sehari-hari.

Pendektan konstruktivisme lebih menekankan pada belajar autentik, bukan pembelajaran artifisial. Belajar autentik adalah proses interaksi sosial peserta didik dengan objek yang di pelajari secara nyata. Belajar bukan sekedar memahami teks-teks (tekstual), yang terpenting ialah bagaimana menghubungkan teks itu dengan kondisi nyata dan kontekstual. Fungsi pertama dalam pembelajaran konstruktivisme ialah mengembangkan kemampuan peserta didik, karena peserta didik adalah manusia yang potensial dan dapat dikembangkan secara optimal melalui proses pendidikan (Sudarmiani, 2003).

Dunia pendidikan sangatlah berperan penting dalam mengembangkan sumber daya manusia. Munculnya berbagai metode, model, dan strategi dalam sebuah pembelajaran, tentulah sangat membantu dan memudahkan baik guru maupun siswa jika penerapan dalam pembelajaran sesuai dengan materi yang akan diajarkan. Banyak manfaat yang diperoleh apabila seorang guru memanfaatkan dan menerapkan suatu model pembelajaran yang kreatif guna memudahkan siswa memahami materi yang akan disampaikan seorang guru. model pembelajaran dapat diartikan sebagai suatu konsep yang membantu menjelaskan proses pembelajaran baik menjelaskan pola pikir maupun pola tindakan pembelajaran tersebut (Ernalis. Syahrudin, 2010).

Selain pendekatan yang menarik, seorang guru juga bisa mengkombinasikan pembelajaran dengan permainan yang edukatif. Hal ini dapat diupayakan guna meningkatkan motivasi serta menjadi pembelajaaran lebih menyenangkan (Dewi Yuni Akhiriyah, 2011). Salah satu permainan yang menarik ialah Snowball Throwing, yaitu permainan bola salju. Bola salju yang dimaksud dalam hal ini ialah kertas yang dibentuk bulat seperti bola salju. Di dalam kertas yang di bentuk bulat tersebut sudah berisi pertanyaan yang siap untuk dilempar ke teman sendiri dan yang mengenai lemparan harus menjawab pertanyaan tersebut (Agustina, 2013).

Peran seorang guru dalam menciptakan situasi belajar yang kreatif sangat dibutuhkan, terlebih dalam ranah pembelajaran sastra yang mencakup langsung kehidupan dan lingkungan siswa, suatu metode dengan cara memecahkan suatu masalah dirasa sangatlah sesuai untuk mengulas suatu 
pembelajaran sastra, sehingga siswa dapat saling bertukar pendapat dengan teman-teman mereka. Semakin kreatif seorang pengajar dalam menyampaikan materi pelajaran, maka akan semakin mudah dan semakin semangat siswa dalam mengikuti materi yang disampaikan oleh seorang guru, proses balajar mengajar pun akan lebih optimal.

Melalui gagasan tersebut, peneliti mencoba menerapkan suatu pendekatan konstruktivisme tipe snowball Throwing untuk meningkatkan kemampuan menulis puisi siswa kelas VII MTs Hidayatul Islamiyah Bumirejo Kecamatan Kepohbaru Kabupaten Bojonegoro. Dengan adanya pendekatan dan metode seperti ini diharapkan kemampuan siswa serta motivasi belajar siswa semakin meningkat.

\section{METODE PENELITIAN}

Penelitian ini merupakan jenis penelitian kualitatif. Penelitian kualitatif merupakan penelitian yang menghasilkan data deskriptif berupa katakata tertulis atau lisan dari orang-orang dan perilaku yang diamati. Penelitian kualitatif bertujuan untuk membangun persepsi alamiah sebuah objek, jadi penelitian mendekatkan diri kepada objek secara utuh (holistic) (Moleong, 1996:6). Yang dimaksud dengan deskriptif adalah pemaparan atau penggambaran dengan kata-kata secara jelas dan terperinci (Depdiknas, 2005:258).

Sedangkan untuk mengumpulkan data peneliti menggunakan teknik observasi, teknik tes, dan teknik kuesioner. Teknik observasi ialah kegiatan pengamatan yang dilakukan secara langsung terhadap siswa di dalam kelas dengan teliti dan sistematis, teknik observasi dilakukan secara langsung pada saat pembelajaran menulis puisi pada siswa kelas VII. Teknik tes ialah memberikan pertanyaan untuk mengukur pengetahuan siswa. Teknik kuesioner ialah sejumlah pertanyaan tertulis yang digunakan untuk memperoleh informasi dari responden tentang pribadinya atau hal-hal yang ia ketahui (Arikunto, 2006:67).

\section{HASIL PENELITIAN}

Berdasarkan hasil tes yang diberikan oleh peneliti terhadap siswa setelah dilakukan pembelajaran dengan menggunakan pendekatan konstruktivisme tipe Snowball Throwing, diperoleh data sebagai berikut:

\begin{tabular}{|c|l|c|c|c|c|c|c|}
\hline \multirow{2}{*}{ No } & \multirow{2}{*}{ Nama Siswa } & \multicolumn{5}{|c|}{ Nilai Praktik Individu } & \multirow{2}{*}{ SN } \\
\cline { 3 - 7 } & & A & B & C & D & JML & \\
\hline 1 & Abdullah Zahid & 25 & 25 & 20 & 20 & 90 & 4 \\
\hline 2 & Andi Pratama & 20 & 25 & 25 & 25 & 95 & 4 \\
\hline 3 & Ayu Setyoningsih & 20 & 20 & 25 & 25 & 90 & 4 \\
\hline 4 & Dewa Putra Dinastiar & 25 & 25 & 20 & 20 & 90 & 4 \\
\hline 5 & Dimas Arinanda & 25 & 25 & 20 & 20 & 90 & 4 \\
\hline 6 & Dita Purnama Sari & 25 & 20 & 25 & 25 & 95 & 4 \\
\hline 7 & Gilang Akbar Gaifari & 20 & 20 & 25 & 25 & 90 & 4 \\
\hline 8 & Ida safitri & 25 & 25 & 20 & 20 & 90 & 4 \\
\hline 9 & Ilma fitrotun zuhriyah & 20 & 25 & 25 & 25 & 95 & 4 \\
\hline 10 & Khoirul rozikin & 20 & 20 & 25 & 25 & 90 & 4 \\
\hline 11 & M. Afif Awaludin & 25 & 25 & 20 & 20 & 90 & 4 \\
\hline 12 & M. Akfin Nurin'in & 25 & 25 & 25 & 25 & 85 & 3 \\
\hline 13 & M. Bayu Saputro & 20 & 20 & 25 & 25 & 80 & 3 \\
\hline
\end{tabular}




\begin{tabular}{|c|c|c|c|c|c|c|c|}
\hline 14 & M. Fahrudin Ma'aruf & 25 & 25 & 25 & 25 & 100 & 5 \\
\hline 15 & M. Rizal Febrianto & 25 & 25 & 25 & 25 & 100 & 5 \\
\hline 16 & M. Rudi & 25 & 25 & 25 & 20 & 85 & 4 \\
\hline 17 & Nur Afni Wulandari & 25 & 25 & 20 & 20 & 85 & 3 \\
\hline 18 & Nur Mita Sari & 25 & 25 & 25 & 25 & 95 & 4 \\
\hline 19 & Putri Puji Lestari & 20 & 25 & 20 & 25 & 90 & 4 \\
\hline 20 & Rohmatin & 20 & 20 & 25 & 25 & 90 & 4 \\
\hline 21 & Vina Selviana & 25 & 25 & 20 & 20 & 90 & 4 \\
\hline 22 & Wahyu Budi Utomo & 25 & 25 & 20 & 20 & 75 & 2 \\
\hline 23 & Ahmad Hadi N & 25 & 25 & 25 & 25 & 95 & 4 \\
\hline \multicolumn{2}{|c|}{ JUMLAH } & \multicolumn{4}{|c|}{-} & 2075 & 89 \\
\hline \multicolumn{2}{|c|}{ RATA-RATA } & \multicolumn{4}{|c|}{ - } & 90,2 & 3,8 \\
\hline
\end{tabular}

Keterangan:

A: Pemilihan judul puisi

B: Pemilihan Kata yang digunakan

C: Keterkaitan isi dengan tema dan judul

D: Penerapan larik, bunyi, bait dan tipografi

SN: Standart Nilai

\section{Standart Nilai :}

$60-69: 1$ (gagal)

$70-79: 2$ (kurang)

$80-89: 3$ (cukup)

$90-99: 4$ (baik)

$100 \quad: 5$ (sangat baik)

Berdasarkan deskripsi data di atas, pembelajaran menulis puisi dengan pendekatan konstruktivisme tipe snowball throwing menunjukkan hasil yang memuaskan. Kriteria nilai secara kelompok masuk dalam kriteria tim hebat. Secara individu, tidak ada siswa yang mendapat nilai kurang. Minimal yang didapatkannya adalah nilai cukup, yaitu 20 poin namun kebanyakan baik, yaitu 25 poin. Hal ini menandakan bahwa siswa tersebut telah mampu memilih judul puisi, pemilihan kata yang digunakan, keterkaitan isi dengan tema dan judul, dan penerapan larik, bunyi, bait, dan tipografi. Adapun kemampuan kognitif siswa dalam memahami pembelajaran tentang puisi juga memperoleh kriteria baik dengan hasil nilai rata-rata 90,2.

\section{Ativitas Siswa dalam Pembelajaran}

Berdasarkan hasil pengamatan yang dilakukan oleh peneliti selama proses pembelajaran terhadap aktivitas siswa, diperoleh data aktivitas sebagai berikut:

\begin{tabular}{|c|c|c|c|c|c|c|c|c|c|c|c|c|c|c|c|}
\hline \multirow{3}{*}{ No } & \multirow{3}{*}{ Nama Siswa } & \multicolumn{10}{|c|}{ Aspek yang diamati } & \multirow{3}{*}{ SKOR } & \multirow{3}{*}{ NILAI } & \multirow{2}{*}{\multicolumn{2}{|c|}{ KET }} \\
\hline & & \multirow{2}{*}{1} & \multirow{2}{*}{2} & \multirow{2}{*}{3} & \multirow{2}{*}{4} & \multirow{2}{*}{5} & \multirow{2}{*}{6} & \multirow{2}{*}{7} & \multirow{2}{*}{8} & \multirow{2}{*}{9} & \multirow{2}{*}{10} & & & & \\
\hline & & & & & & & & & & & & & & $\mathrm{A}$ & TA \\
\hline 1 & Abdullah Zahid & 10 & 9 & 6 & 7 & 10 & 10 & 9 & 8 & 10 & 10 & 89 & 89 & $\sqrt{ }$ & - \\
\hline 2 & Andi Pratama & 8 & 8 & 9 & 7 & 6 & 10 & 8 & 8 & 9 & 7 & 80 & 80 & $\sqrt{ }$ & - \\
\hline 3 & Ayu Setyoningsih & 7 & 9 & 8 & 8 & 8 & 9 & 10 & 9 & 8 & 6 & 82 & 82 & $\sqrt{ }$ & - \\
\hline 4 & Dewa Putra Dinastiar & 7 & 9 & 9 & 9 & 7 & 10 & 8 & 7 & 6 & 7 & 79 & 79 & $\sqrt{ }$ & - \\
\hline
\end{tabular}




\begin{tabular}{|c|l|c|c|c|c|c|c|c|c|c|c|c|c|c|c|}
\hline 5 & Dimas Arinanda & 8 & 6 & 6 & 7 & 8 & 10 & 8 & 7 & 8 & 7 & 69 & 69 & - & $\sqrt{ }$ \\
\hline 6 & Dita Purnama Sari & 9 & 10 & 8 & 6 & 7 & 10 & 9 & 8 & 9 & 7 & 81 & 81 & $\sqrt{ }$ & - \\
\hline 7 & Gilang Akbar Gaifari & 10 & 8 & 8 & 7 & 9 & 9 & 7 & 9 & 8 & 8 & 77 & 77 & $\sqrt{ }$ & - \\
\hline 8 & Ida safitri & 8 & 6 & 7 & 8 & 9 & 7 & 8 & 8 & 7 & 6 & 72 & 72 & $\sqrt{ }$ & - \\
\hline 9 & Ilma fitrotun zuhriyah & 9 & 9 & 7 & 7 & 8 & 7 & 9 & 7 & 9 & 7 & 77 & 77 & $\sqrt{ }$ & - \\
\hline 10 & Khoirul rozikin & 9 & 7 & 6 & 7 & 6 & 8 & 8 & 9 & 8 & 6 & 74 & 74 & $\sqrt{ }$ & - \\
\hline 11 & M. Afif Awaludin & 7 & 8 & 7 & 8 & 7 & 9 & 7 & 6 & 8 & 6 & 73 & 73 & $\sqrt{ }$ & - \\
\hline 12 & M. Akfin Nurin'in & 8 & 9 & 8 & 7 & 8 & 10 & 8 & 7 & 6 & 6 & 73 & 73 & $\sqrt{ }$ & - \\
\hline 13 & M. Bayu Saputro & 6 & 7 & 10 & 8 & 8 & 10 & 6 & 8 & 7 & 7 & 77 & 77 & $\sqrt{ }$ & - \\
\hline 14 & M. Fahrudin Ma'aruf & 8 & 8 & 9 & 9 & 9 & 9 & 7 & 9 & 7 & 8 & 80 & 80 & $\sqrt{ }$ & - \\
\hline 15 & M. Rizal Febrianto & 9 & 8 & 10 & 6 & 7 & 9 & 9 & 6 & 7 & 6 & 75 & 75 & $\sqrt{ }$ & - \\
\hline 16 & M. Rudi & 8 & 9 & 9 & 8 & 9 & 7 & 7 & 8 & 7 & 6 & 76 & 76 & $\sqrt{ }$ & - \\
\hline 17 & Nur Afni Wulandari & 10 & 9 & 6 & 9 & 8 & 7 & 8 & 6 & 9 & 6 & 78 & 78 & $\sqrt{ }$ & - \\
\hline 18 & Nur Mita Sari & 10 & 9 & 8 & 8 & 10 & 8 & 9 & 9 & 7 & 8 & 83 & 83 & $\sqrt{ }$ & - \\
\hline 19 & Putri Puji Lestari & 9 & 8 & 6 & 9 & 8 & 9 & 6 & 9 & 6 & 7 & 75 & 75 & $\sqrt{ }$ & - \\
\hline 20 & Rohmatin & 8 & 7 & 9 & 8 & 7 & 6 & 8 & 9 & 6 & 6 & 72 & 72 & $\sqrt{ }$ & - \\
\hline 21 & Vina Selviana & 9 & 10 & 8 & 9 & 9 & 7 & 9 & 9 & 7 & 8 & 83 & 83 & $\sqrt{ }$ & - \\
\hline 22 & Wahyu Budi Utomo & 8 & 7 & 10 & 6 & 7 & 6 & 8 & 6 & 6 & 6 & 69 & 69 & - & $\sqrt{ }$ \\
\hline 23 & Ahmad Hadi N & 7 & 9 & 8 & 7 & 8 & 9 & 7 & 8 & 8 & 6 & 77 & 77 & $\sqrt{ }$ & - \\
\hline & \multicolumn{10}{|c|}{ JUMLAH } \\
\hline
\end{tabular}

Berdasarkan data tersebut, dengan jumlah siswa sebanyak 23 diperoleh data sebaran aktifitas siswa diperoleh data jumlah siswa setiap dalam pembelajaran menulis puisi aktifitas sebagai berikut:

\begin{tabular}{|l|l|c|c|c|c|}
\hline No & \multicolumn{1}{|c|}{ Aktifitas } & $\begin{array}{c}\text { Baik } \\
(\mathbf{1 0})\end{array}$ & $\begin{array}{c}\text { Cukup } \\
\mathbf{( 8 - 9 )}\end{array}$ & $\begin{array}{c}\text { Kurang } \\
(\mathbf{6 - 7})\end{array}$ & Jumlah \\
\hline 1 & Perhatian ketika menerima materi & 4 & 14 & 5 & 23 \\
\hline 2 & Kesungguhan menjalankan tugas & 2 & 15 & 6 & 23 \\
\hline 3 & $\begin{array}{l}\text { Partisipasi pembentukan } \\
\text { kelompok }\end{array}$ & 3 & 12 & 8 & 23 \\
\hline 4 & Ketertiban melempar bola kertas & - & 12 & 11 & 23 \\
\hline 5 & Keaktifan & 2 & 13 & 8 & 23 \\
\hline 6 & Kualitas ide atau gagasan & 7 & 9 & 7 & 23 \\
\hline 7 & $\begin{array}{l}\text { Tingkat pemahaman terhadap } \\
\text { materi }\end{array}$ & 1 & 15 & 7 & 23 \\
\hline 8 & Pendemonstrasian hasil tugas & - & 15 & 8 & 23 \\
\hline 9 & Pertanyaan siswa & 1 & 10 & 12 & 23 \\
\hline
\end{tabular}




\begin{tabular}{|l|l|l|l|l|l|}
\hline 10 & Tanggapan siswa & 1 & 4 & 18 & 23 \\
\hline
\end{tabular}

Dari hasil aktivitas pada tabel 4.1 di atas, aktivitas siswa dalam pembelajaran menulis puisi ternyata siswa yang mendapat nilai $<70-75$ (Tidak Aktif) ada 2 siswa $(8,7 \%)$, sedangkan siswa yang mencapai nilai 75 89 (Aktif) sebanyak 21 siswa $(91,3 \%)$. Hal ini menunjukkan bahwa aktivitas siswa selama mengikuti proses pembelajaran menulis puisi melalui pendekatan konstruktivisme tipe snowball throwing kelas VII MTs Hidayatul Islamiyah Bumirejo efektif diterapkan, ditinjau dari tingkat aktivitas belajar siswa.

\section{Respon Siswa Terhadap Proses Pembelajaran}

Berdasarkan hasil sebaran angket yang diberikan peneliti terhadap siswa untuk meninjau respon siswa terhadap strategi pembelajaran dengan menggunakan pendekatan konstruktivisme tipe Snowball Throwing pada siswa kelas VII MTs Hidayatul Islamiyah Bumirejo, maka diperoleh hasil dari responden sebagai berikut:

\begin{tabular}{|c|c|c|c|c|c|c|c|c|}
\hline \multirow[b]{2}{*}{ No } & \multirow[b]{2}{*}{$\begin{array}{l}\text { Hal-hal yang perlu } \\
\text { direspon siswa }\end{array}$} & \multicolumn{3}{|c|}{ Skor } & \multirow[b]{2}{*}{$\begin{array}{c}\text { juml } \\
\text { ah }\end{array}$} & \multicolumn{3}{|c|}{ Prosentase \% } \\
\hline & & $\begin{array}{l}\mathrm{Ya} \\
\text { (3) }\end{array}$ & $\begin{array}{c}\text { Kurang } \\
\text { (2) }\end{array}$ & $\begin{array}{l}\text { Tidak } \\
\text { (1) }\end{array}$ & & 3 & 2 & 1 \\
\hline 1 & $\begin{array}{l}\text { Apakah kamu merasa } \\
\text { senang dengan } \\
\text { pembelajaran ini? }\end{array}$ & 19 & 4 & - & 23 & 82,6 & 17,3 & - \\
\hline 2 & $\begin{array}{l}\text { Menurut kamu, apakah } \\
\text { belajar menulis puisi } \\
\text { dengan pendekatan } \\
\text { konstruktivisme tipe } \\
\text { Snowball Throwing ini } \\
\text { lebih menyenangkan? }\end{array}$ & 19 & 4 & - & 23 & 82,6 & 17,3 & - \\
\hline 3 & $\begin{array}{l}\text { Menurutmu apakah } \\
\text { kegiatan belajar hari ini } \\
\text { dapat meningkatkan hasil } \\
\text { belajar kalian? }\end{array}$ & 10 & 13 & - & 23 & 43,4 & 56,5 & - \\
\hline 4 & $\begin{array}{l}\text { Apakah guru dapat } \\
\text { membimbing kamu dalam } \\
\text { kegiatan belajar mengajar? }\end{array}$ & 15 & 8 & - & 23 & 65,2 & 34,7 & - \\
\hline 5 & $\begin{array}{l}\text { Apakah pendekatan } \\
\text { konstruktivisme tipe } \\
\text { Snowball Thrawing ini } \\
\text { tepat untuk diterapkan } \\
\text { dalam pembelajaran } \\
\text { menulis puisi? }\end{array}$ & 14 & 9 & - & 23 & 60,8 & 39,1 & - \\
\hline & Rata-rata & & & & & $\begin{array}{c}66,9 \\
2\end{array}$ & $\begin{array}{c}32,9 \\
8\end{array}$ & 0 \\
\hline
\end{tabular}


Dari tabel tersebut, dapat di rinci dengan tabel sebagai berikut:

\begin{tabular}{|l|l|l|l|l|l|l|c|}
\hline \multirow{2}{*}{ No } & \multirow{2}{*}{ Nama Siswa } & \multicolumn{5}{|c|}{$\begin{array}{c}\text { Aspek yang direspon } \\
\text { siswa }\end{array}$} \\
\cline { 3 - 7 } & & 1 & 2 & 3 & 4 & 5 & \\
\hline 1 & Abdullah Zahid & 3 & 3 & 3 & 3 & 2 & 14 \\
\hline 2 & Andi Pratama & 3 & 2 & 2 & 3 & 2 & 12 \\
\hline 3 & Ayu Setyoningsih & 3 & 2 & 2 & 3 & 3 & 13 \\
\hline 4 & Dewa Putra Dinastiar & 3 & 3 & 2 & 3 & 2 & 13 \\
\hline 5 & Dimas Arinanda & 3 & 2 & 3 & 3 & 3 & 14 \\
\hline 6 & Dita Purnama Sari & 3 & 3 & 2 & 3 & 3 & 14 \\
\hline 7 & Gilang Akbar Gaifari & 3 & 3 & 3 & 3 & 2 & 14 \\
\hline 8 & Ida safitri & 3 & 2 & 2 & 3 & 2 & 12 \\
\hline 9 & Ilma fitrotun zuhriyah & 2 & 3 & 2 & 2 & 2 & 11 \\
\hline 10 & Khoirul rozikin & 3 & 3 & 2 & 3 & 3 & 14 \\
\hline 11 & M. Afif Awaludin & 2 & 3 & 2 & 3 & 3 & 13 \\
\hline 12 & M. Akfin Nurin'in & 3 & 3 & 2 & 2 & 3 & 13 \\
\hline 13 & M. Bayu Saputro & 3 & 3 & 3 & 2 & 3 & 14 \\
\hline 14 & M. Fahrudin Ma'aruf & 2 & 3 & 3 & 2 & 3 & 13 \\
\hline 15 & M. Rizal Febrianto & 3 & 3 & 3 & 3 & 3 & 15 \\
\hline 16 & M. Rudi & 3 & 3 & 2 & 3 & 2 & 13 \\
\hline 17 & Nur Afni Wulandari & 3 & 3 & 3 & 3 & 3 & 15 \\
\hline 18 & Nur Mita Sari & 3 & 3 & 3 & 2 & 2 & 13 \\
\hline 19 & Putri Puji Lestari & 2 & 3 & 3 & 2 & 3 & 13 \\
\hline 20 & Rohmatin & 3 & 3 & 2 & 2 & 2 & 12 \\
\hline 21 & Vina Selviana & 3 & 3 & 2 & 3 & 3 & 14 \\
\hline 22 & Wahyu Budi Utomo & 3 & 3 & 2 & 2 & 3 & 13 \\
\hline 23 & Ahmad Hadi N & 3 & 3 & 3 & 3 & 3 & 15 \\
\hline & Jumlah & 65 & 65 & 56 & 61 & 60 & 307 \\
\hline & & & & & \\
\hline
\end{tabular}

Dari data respon siswa pada tabel tersebut tentang pembelajaran menulis puisi melalui pendekatan konstruktivisme tipe snowball throwing persentase respon siswa yang merespon (Ya) 66,92\% dan siswa yang merespon (Kurang) 39,98\%, sedangkan siswa yang merespon (Tidak) $0 \%$, ini menunjukan bahwa respon siswa terhadap pendekatan konstruktivise tipe snowball throwing efektif diterapkan pada materi menulis puisi kelas VII MTs Hidayatul Islamiyah Bumirejo.

\section{SIMPULAN}

Berdasarkan proses pembelajaran yang dilakukan oleh peneliti dengan menggunakan pendekatan Konstruktivisme tipe Snowball Throwing diperoleh nilai yang sangat memuaskan, yakni pemerolehan kemampuan kognitif siswa dalam memahami pembelajaran tentang puisi dengan hasil nilai rata-rata 90,2 . Sedangkan aktivitas siswa diperoleh kesimpulan sebesar 91,3\% siswa aktif dalam pembelajaran, dan $8,7 \%$ siswa tidak aktif, atau 21 siswa tercatat aktif 
dan 2 siswa tercatat tidak aktif selama proses pembelajran dengan pendekatan konstruktivisme tipe snowball throwing. Respon siswa dalam pembelajran menulis puisi dengan pendekatan konstruktivisme tipe snowball throwing telah diketahui setelah guru memberikan sebaran angket kepada siswa dan diperoleh hasil respon dengan persentase yang merespon (Ya) sebesar 66,92\%, dan siswa yang merespon (Kurang) sebesar 39,98\%, sedangkan siswa yang merespon (tidak) $0 \%$. Hal ini menunjukan pendekatan konstruktivisme tipe snowball throwing dalam pembelajran menulis puisi kelas VII Mts Hidayatul Islamiyah Bumirejo efektif dilakukan ditinjau dari respon siswa.

\section{DAFTAR RUJUKAN}

Agustina, E. T. (2013). IMPLEMENTASI MODEL PEMBELAJARAN SNOWBALL THROWING UNTUK MENINGKATKAN HASIL BELAJAR SISWA DALAM MEMBUAT PRODUK KRIA KAYU DENGAN. Invotec, IX(1), $17-28$.

Dewi Yuni Akhiriyah. (2011). Pembelajaran, Penerapan Model
Intructional, Social Fifth, A T. KREATIF Jurnal Kependidikan Dasar, 1, 206-219.

Ernalis. Syahrudin, D. A. Y. (2010). Dosen PGSD Universitas Pendidikan Indonesia Kampus Cibiru. Eduhumaniora, 1-11.

Sudarmiani. (2003). MEMBANGUN KARAKTER ANAK DENGAN BUDAYA KEARIFAN LOKAL DALAM PROSES PEMBELAJARAN DI SEKOLAH. EQUILIBRIUM, (20), 54-72.

Sularmi. (2018). Penerapan Teori Konstruktivisme untuk Meningkatkan Prestasi Belajar PKn Pada Siswa Kelas VI SD Negeri 1 Punjul Tulungagung. BRILIANT: Jurnal Riset Dan Konseptual, 3(2), 165-174.

Yusnimarniarti. (2016). PENINGKATAN KETERAMPILAN KONSTRUKSI DENGAN PENDEKATAN KONSTRUKTIVISME DI KELAS IV SD NEGERI 04 BATANG ANAI KABUPATEN PADANG PARIAMAN. Jurnal Konseling Dan Pendidikan, 4(1), 53-58. 